\title{
Ecomorphological and taphonomic gradients in clypeasteroid-dominated echinoid assemblages along a mixed siliciclastic-carbonate shelf from the early Miocene of northern Sardinia, Italy
}

\author{
Andrea Mancosu and James H. Nebelsick \\ Acta Palaeontologica Polonica 62 (3), 2017: 627-646 doi:https://doi.org/10.4202/app.00357.2017
}

Clypeasteroid echinoids are widespread and abundant within Miocene sedimentary sequences of the Mediterranean area within both siliciclastic and carbonate deposits. Herein, three clypeasteroid-dominated echinoid assemblages from the mixed siliciclastic-carbonate succession of the Mores Formation (lower Miocene) cropping out within the Porto Torres Basin (northern Sardinia) are described. These assemblages were compared to previously described clypeasteroid-bearing deposits from the Miocene of northern Sardinia with the purpose of investigating their palaeoecology and taphonomy along a shelf gradient. These goals are accomplished by various methods including (i) logging sedimentary facies, (ii) analysing the functional morphology of sea urchin skeletons, (iii) comparing the relative abundance of taxa and taphonomic features, and (iv) studying associated fauna, flora, and trace fossils. The clypeasteroid-bearing deposits differ greatly with respect to echinoid diversity, accompanying fauna and flora, sedimentological signatures, and taphonomic features. They also show variations in depositional environments and the mechanism of formation of the deposits. Three different shelf settings are distinguished: littoral, inner sublittoral, and outer sublittoral environments. Furthermore, an ecomorphological gradient along the shelf is recognized with respect to echinoid taxa and their morphologies. This gradient ranges from shallow water to a moderately deep shelf and is interpreted with respect to both abiotic and biotic factors as well as the taphonomy of the echinoid tests.

Key words: Echinoidea, taphonomy, functional morphology, palaeoecology, Miocene, Sardinia.

Andrea Mancosu [andrea.mancosu@gmail.com], Dipartimento di Scienze Chimiche e Geologiche, Università degli studi di Cagliari, Via Trentino 51, 09127 Cagliari, Italy. James H. Nebelsick [nebelsick@uni-tuebingen.de], Institut für Geowissenschaften, Universität Tübingen, Sigwartstraße 10, D-72076 Tübingen, Germany. 
Attribution License (for details please see creativecommons.org), which permits unrestricted use, distribution, and reproduction in any medium, provided the original author and source are credited.

Fof Full text $(1,158.2 \mathrm{kB})$ 